\title{
Energy and carbon footprints of different technologies for energy recovery from wastewater of the Vietnamese seafood processing industry
}

\author{
So sánh lương năng lương và dấu chân carbon tù các công nghệ thu hồi năng \\ lượng tù̀ nước thải chế biến thủy sản tại Việt Nam
}

Research article

Dziomba, Henri*; Trautmann, Niklas; Rosenwinkel, Karl-Heinz

Leibniz University Hannover, Institute for Sanitary Engineering and Waste Management, Welfengarten 1, 30167 Hannover, Germany

\begin{abstract}
The treatment of industrial wastewater with high organic loads has a large potential for energy recovery and the reduction of greenhouse gas emissions. In this work, the energy and carbon footprints of diff erent process technologies for the treatment of fat rich wastewater from the Vietnamese seafood industry have been examined. Three options have been compared: the current low-tech solution in which the fat is used as an input for biodiesel production, the anaerobic treatment of the fat with power generation from the biogas and a combined option in which the fat is converted into biodiesel and the effl uent is pre-treated anaerobically. Energy consumption and recovery as well as other emission sources have been analysed during the construction and operation phase of the plants, while the demolition phase has been neglected. All analysed options have a positive net energy output which sums up to $4.17 ; 4.44$ and $9.82 \mathrm{kWh}$ per treated $\mathrm{m}^{3}$ of wastewater for variants 1 , 2 and 3 respectively. The corresponding carbon footprints are -0.90 . -0.69 and $-2.24 \mathrm{KgCO}_{2} / \mathrm{m}^{3}$. Hence, anaerobic digestion of the fat can slightly improve the net energy output but performs even worse on the carbon footprint of the treatment plant, whereas the combination of biodiesel production and anaerobic pre-treatment reduces energy consumption during the operational phase and recovers more than twice as much energy as the other options. Furthermore, all variants have a negative carbon footprint and thus save $\mathrm{CO}_{2}$-emissions, since the carbon in the wastewater is biogenic and the recovered energy can replace fossil fuels.
\end{abstract}

Việc xử lý nước thải công nghiệp với hàm luợng hũu cơ cao có tiềm năng rất lớn trong việc thu hồi năng lượng và làm giảm phát thải khí nhà kính. Trong nghiên cưu này, luợng năng luợng và khi thải gây ô nhiếm môi truờng (dấu chân Carbon) tù các công nghệ xủ lý nuớc thái giàu chất béo ngành công nghiệp chế biến thủy sản tại Việt Nam đã được nghiên cưu. 3 phuơng pháp đã được so sánh: giải pháp hiện tại sử dụng chất béo làm nguyên liệu sản xuất diesel sinh hoc; phuơng pháp xủ lý ky khí chất béo có sản sinh năng luợng và phuơng pháp kết hơp trong đó chất béo được chuyển thành diesel sinh học và nước thải đầu ra được xủ lý ky khí. Lượng năng luợng tiêu thụ và thu hồi cũng nhu các nguồn phát thải khác đều đã được phân tích trong suốt quá trình xây dựng và vận hành nhà máy. Các phuoong pháp phân tích đều cho kết quả tích cực về mặt năng lương, chẳng hạn nhu $1 \mathrm{~m}^{3}$ nước thải tạo ra lần lượt 5,24; 4,56 và 11,16 $\mathrm{kWh}$ tuoong úng với các phuơng pháp 1, 2, 3. Lượng $\mathrm{CO}_{2}$ lần lượ là 0,90; 0,69 và 2,24 $\mathrm{Kg} \mathrm{CO}_{2} / \mathrm{m}^{3}$. Do đó, xủ lý ky khí chất béo không thể cải thiện lượng năng lương đầu ra hoạc dấu chân carbon của nhà máy xủ lý, trong khi việc kết hợp sản xuất diesel sinh học và tiền xủ lý ky khi làm giảm luợng năng luợng tiêu thu trong quá trình vận hành và thu hồi lượng năng lương nhiều gấp 2 lần các phuơng pháp khác. Ngoài ra, các phuơng pháp đều tạo ra giá trị dấu chân carbon âm, tức là làm giảm luợng phát thái $\mathrm{CO}_{2}$, vì carbon trong nuớc thải là carbon sinh học và năng lương thu hồi có thể thay thế nhiên liệu hóa thạch.

Keywords: $\quad$ wastewater, carbon footprint, greenhouse gas, energy, seafood industry 


\section{Introduction}

Due to the public discussion about climate change, the carbon and energy balances of products and services have come into focus. Wastewater treatment facilities generally have high energy consumption and therefore high indirect $\mathrm{CO}_{2}$-emissions, since in most countries the electricity is mainly produced by fossil resources. Technologies for energy recovery from carbon rich wastewaters such as anaerobic treatment with biogas production have been introduced in the literature (Cakir \& Stenstrom, 2005; Shahabadi et al., 2009) and are able to gain a net energy output as well as overall net $\mathrm{CO}_{2}$-savings treating wastewater with high organic loads. Animal fat can also be converted into biodiesel (Jayasinghe and Hawboldt, 2012) which is a more flexible energy source compared to biogas, due to its good transportability.

The wastewater of most seafood processing companies in the Mekong Delta contains high loads of carbon in the form of fish fat and is conventionally treated aerobically (Trautmann et al., 2011). This results in high energy demands and high amounts of excess sludge that may not always be treated adequately. The fish fat is extracted, transported to China and converted to biodiesel. With an annual production of 566 million liters in 2012 and much higher capacities, biodiesel technology has long been applied on a large scale in China (Meador, 2012). Anaerobic treatment would have the advantage that electricity could be produced on site with a cogeneration unit, which would make the companies less dependent on the often instable national grid. In the present work, the energy and carbon footprints of the conventional treatment method have been compared to those of two different variants. One of them implies the anaerobic digestion of the fat and conversion of the resulting biogas to electricity and heat, the other one is a combination of biodiesel production of the fat and anaerobic pretreatment of the remaining wastewater.

\section{Plant design and calculation meth- odology}

\subsection{Plant description}

The assumptions for the modeling of the three wastewater treatment variants are based on on-site collected data of wastewater parameters of the fish processing industry in southern Vietnam. Typical wastewater parameters at a fish processing site have been assumed as shown in Table 1. The plants have been designed for a cleaning capacity of $1,000 \mathrm{~m}^{3}$ per day that ensures to comply with the regional Vietnamese regulations at the point of wastewater discharge. Those were calculated to be $55 \mathrm{mg} / \mathrm{l} \mathrm{COD}$ and $33 \mathrm{mg} / \mathrm{l}$ nitrogen according to the Vietnamese Ministry of Natural Resources and Environment (VEA, 2008).

Regarding the operation of the plant, it has been assumed that a constant wastewater inflow of $100 \mathrm{l} / \mathrm{h}$ is occurring for 10 hours on weekdays. Furthermore, an average temperature of $25^{\circ} \mathrm{C}$ has been assumed. Fluctuations in wastewater inflow as well as temperature have been neglected.
Table 1. Typical wastewater parameters of a Vietnamese fish processing factory

\begin{tabular}{lcr}
\hline Parameter & Unit & Value \\
\hline COD & {$[\mathrm{mg} / \mathrm{l}]$} & 4,200 \\
Total Nitrogen & {$[\mathrm{mg} / \mathrm{l}]$} & 140 \\
Solids (fat) & {$[\% \mathrm{Vol}]$.} & 4 \\
N content fat & {$[\mathrm{mg} / \mathrm{Kg}]$} & 40 \\
\hline
\end{tabular}

A simplified flowchart of the different variants is given in Figure 1. Variant 1 shows the typical low technology option currently used for wastewater treatment in the Vietnamese fish industry. A large part of the sediments is extracted from the inflow with a simple grease trap, the remaining wastewater is treated aerobically to meet the effluent standards. The fat is transported to China where it is converted into biodiesel while possible leftovers of this process are neglected. The excess sludge is lead to sludge disposal.

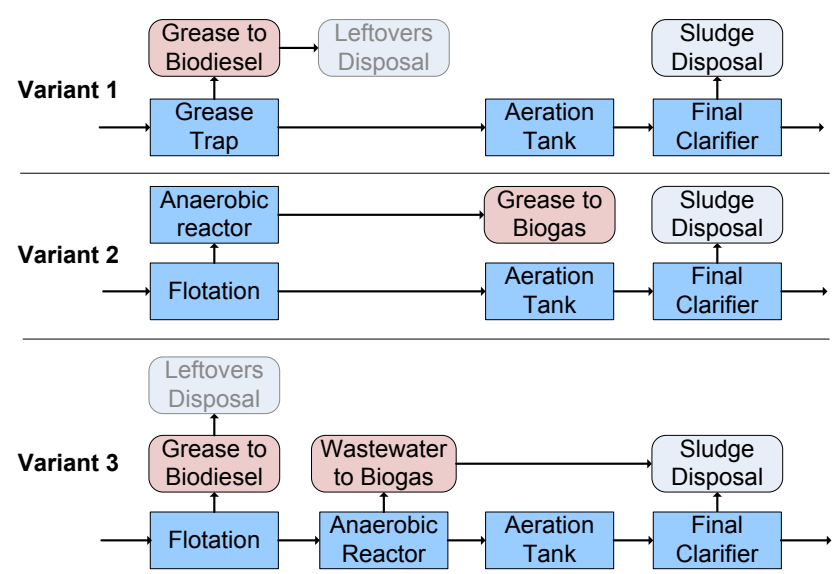

Figure 1. Overview process variants

Variant 2 operates with a precipitation-supported flotation to achieve a more effective extraction of the fat, which then is converted into biogas in a two-step anaerobic reactor. A biogas powered cogeneration unit provides the factory with electricity while the excess heat is used as input energy for absorption chillers. Despite the more effective fat extraction, remaining wastewater has to be post-treated aerobically to meet the effluent standards.

Variant 3 represents a combination of both of the previous variants. The fat is extracted by flotation and sent to biodiesel production while the remaining wastewater with sufficiently high COD loadings is pre-treated anaerobically and post-treated aerobically. Since the anaerobic pretreatment extracts only small part of the nitrogen load, this variant requires an additional denitrification unit to meet the effluent standards.

Excess sludge disposal is carried out in dry beets without previous dewatering in all variants.

\subsection{System boundaries}

In the calculation of $\mathrm{CO}_{2}$ emissions, construction and operation of the plants were considered. There is a consensus within the literature that the demolition phase of wastewater treatment plants is irrelevant for the carbon footprint (Larsen et al., 2007) and, moreover, shut down 
plants are not necessarily deconstructed and recycling rates as well as emission factors can hardly be estimated over a predicted lifespan of 15 years. Hence, the demolition phase of the plant is neglected in the calculation. Figure 2 shows an overview on the system boundaries.

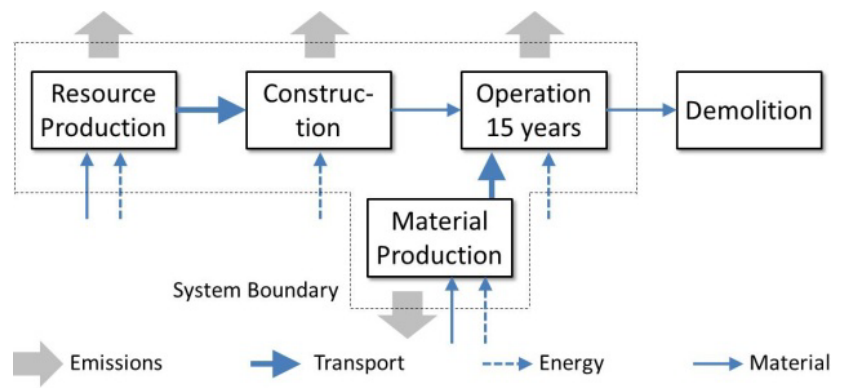

Figure 2. System boundaries and life cycle

\subsection{Calculation of energy demand and $\mathrm{CO}_{2}-$ emissions}

Since there hasn't been a generally admitted norm for the calculation of carbon footprints yet, this work's calculation is based on the PAS manual (PAS2050, 2011) published by the British Standards Institution BSI, which has proven to be practical. Energy demand and emissions resulting from construction and operation of the plant have completely been taken from literature and manufacturers data. Direct emissions only result from dissolved methane in the discharge of anaerobic reactors, which have been calculated using Henry's law. Direct emissions from the aerobic treatment are considered biogenic and therefore, referring to IPCC, do not contribute to the carbon footprint (Doorn et al., 2006).

For the embodied emissions of resources, emission factors from Gemis (Öko Institut e.V., 2010) and Idemat (TU Delft, 2010) databases were applied. The necessary quantities of construction materials were taken from contract documents of existing plants that resemble the ones analyzed in this paper. The quantities were up- or downscaled to the designed size. The energy demand was determined using literature data from Zhang and Wilson (2000), who used a factor for energy demand per $\mathrm{m}^{2}$ of required surface area for the plant. It was assumed that the energy used for construction consists of $90 \%$ diesel and $10 \%$ electricity taken from the national grid, as transport and most of the construction machinery is powered by diesel fuel.

The transport of construction material, chemicals and excess sludge was assumed to be realized by truck over a distance of 50, 20 and $10 \mathrm{~km}$ respectively. Since biodiesel production usually is carried out in China, the fat is transported 2,000 $\mathrm{km}$ by train. For the estimation of the energy consumption during plant operation, electrical installations, including electric power and hours of operation, have been designed referring to literature and manufacturers data. An overview of operation parameters and electrical power consumers with the corresponding sources is given in Table 2 .

\subsection{Allocation of emissions}

The processes analyzed in this paper produce as byproduct either biogas, biodiesel or both. Those byproducts were assumed to be biogenic and therefore lead to a saving of $\mathrm{CO}_{2}$-emissions when replacing fossil fuels. Since fossil diesel can directly be replaced by biodiesel, 1 $\mathrm{kg}$ of biodiesel produced accounts for a saving of 3,71 $\mathrm{kg}_{\mathrm{CO} 2}$ less the amount of emissions resulting from the conversion process of the fat (Jensen et al., 2007; López et al., 2010) and from the transport to China.

Biogas is usually converted to electricity in cogeneration units, so that the emission savings depend on the application of electricity and heat. It was assumed that the electricity could completely be used in the factories on site, so that it substitutes electricity from the national grid. The heat is used as input energy for absorption chillers that cool the storage rooms. Since the cooling is conventionally done by electrical compression chillers, there is also a saving of grid electricity to be calculated. The latest Vietnamese grid emission factor available is $0.57 \mathrm{~kg}_{\mathrm{CO} 2} / \mathrm{kWh}_{\mathrm{el}}$ (Quách, 2009).

Assumptions concerning the recycling of the used resources would have a high uncertainty due to the long lifespan of 15 years. However, the applied databases provide a typical market mix for most resources used in the designed plants, which is composed of a certain share of new and recycled material. Apart from that, recycling of resources has been neglected.

\section{Results and discussion}

\subsection{Energy footprint}

A comparison of the energy consumption of the different variants is given in Figure 3. All three variants recover more energy than the treatment demands, so that they produce a net energy output. Regarding the high rates of energy recovery, energy consumption for construction and operation phase is almost insignificant. The demand for construction includes transport of materials, resource production and energy demand on site. It sums up to 0.10 , 0.21 and $0.18 \mathrm{kWh} / \mathrm{m}^{3}$ ww for variants 1,2 and 3 respectively, and thus can be neglected. In the operation phase, aeration is by far the largest consumer. Pumps, flotation, stirring, clarifier and transport of excess sludge and chemicals can also be neglected. The total energy consumption in the operation phase sums up to $1.44,1.36$ and 0.84 $\mathrm{kWh} / \mathrm{m}^{3}{ }_{\mathrm{ww}}$ for the three variants.

Anaerobic conversion of the fat with an effective fat extraction by flotation in variant 2 shows a lower energy demand for aeration compared to variant 1 , whereas there is additional demand for pumps, flotation and stirring. The energy recovery of $6.02 \mathrm{kWh} / \mathrm{m}^{3}$ ww as well as the net energy output of $4.44 \mathrm{kWh} / \mathrm{m}^{3}$ ww result to be slightly higher compared to variant 1 with a recovery of 5.72 at a net energy output of $4.17 \mathrm{kWh} / \mathrm{m}^{3}{ }_{\text {ww }}$. The transport of the fat and energy demand of the conversion process have been subtracted from the total amount of energy recovered by biodiesel. 
In variant 3 , a total energy recovery of $10.84 \mathrm{kWh} / \mathrm{m}^{3}{ }_{\text {ww }}$ can be achieved of which biogas accounts for 3.72 $\mathrm{kWh} / \mathrm{m}^{3}{ }_{\mathrm{ww}}$ and biodiesel for $7.12 \mathrm{kWh} / \mathrm{m}^{3}$ ww. In contrast to variant 1 , the more effective flotation extracts a higher amount of fat so that more biodiesel can be produced. Furthermore, variant 3 shows the lowest energy demand of all variants. While pumps, flotation and stirring require more energy than in the other variants, aeration energy is reduced to a minimum as most of the COD loading is extracted anaerobically in the pretreatment. In total, a net energy output of $9.82 \mathrm{kWh} / \mathrm{m}^{3}{ }_{\text {ww }}$ can be achieved, which is more than twice as much as in the previous variants.

Table 2. Overview process parameters and energy demand (values in parenthesis for variant 3, when differing)

\begin{tabular}{|c|c|c|}
\hline Parameter & Value & Source \\
\hline \multicolumn{3}{|l|}{ Wastewater } \\
\hline Flow rate & $100 \mathrm{~m}^{3}{ }_{\mathrm{WW}} / \mathrm{h}$ & \\
\hline Operating times on weekdays & $10 \mathrm{~h}$ & \\
\hline COD & $4,200 \mathrm{mg} / \mathrm{l}$ & \\
\hline Total nitrogen & $140 \mathrm{mg} / \mathrm{l}$ & \\
\hline Temperature & $25^{\circ} \mathrm{C}$ & \\
\hline \multicolumn{3}{|l|}{ Aeration Tank } \\
\hline Retention time & $1(0.5) \mathrm{d}$ & Assumption \\
\hline Standard Aeration Efficiency & $1,30 \mathrm{Kg} \mathrm{O}_{2} / \mathrm{kWh}$ & (Rosso et al., 2008) \\
\hline Aerobic yield & $0.67 \mathrm{~kg} \mathrm{COD} / \mathrm{Kg} \mathrm{COD}$ eli & (Henze et al., 2000) \\
\hline N-fixing & $0.045 \mathrm{Kg} \mathrm{N} / \mathrm{KgCOD}_{\mathrm{eli}}$ & (Gujer, 2007) \\
\hline Oxygen saturation & $2 \mathrm{mg} / \mathrm{l}$ & (Gori et al., 2011) \\
\hline Mean cell residence time & $3 \mathrm{~d}$ & Assumption \\
\hline Recirculation rate denitrification & $(5) d$ & Assumption \\
\hline
\end{tabular}

\section{Flotation}

Efficiency

Power consumption

Ferric chloride dosing

\section{Pre-acidification}

Power consumption

\section{Anaerobic reactor}

Process technology

Retention time

Anaerobic yield

Metabolic rate

Methane production

Power consumption

pH-adjustement

\section{Final clarifier}

Surface area

Power consumption

Return sludge ratio

Return sludge density

\section{Pumps}

Power cons. centrifugal pump

Power cons. eccentric screw pump

\section{Energy recovery}

Electrical eff. cogen. unit

Thermal eff. cogen. unit

Performance ratio $\mathrm{AC}^{*}$

Performance ratio $\mathrm{CC}$

$\mathrm{CO}_{2 \text { eq }}$ electricity Vietnam

$\mathrm{CO}_{2 \mathrm{eq}}$ natural gas

$4 \%$ Vol., $56 \%$ COD

$0.1 \mathrm{kWh} / \mathrm{m}^{3}{ }_{\mathrm{WW}}$ $0.5 \mathrm{~g} \mathrm{FeCL}_{2} / \mathrm{Kg} \mathrm{COD}_{\text {eli }}$

(Steinke and Barjenbruch, 2010)

(Trautmann et al., 2011) Own experiments

$0.24 \mathrm{kWh} /\left(\mathrm{m}^{3}{ }_{\mathrm{Vol}} * \mathrm{~d}\right)$

(Urban, 2008)

\section{CSTR (with sec. sedimentation)}

$$
20 \text { (1) d }
$$$$
0.05
$$

$80(70) \%$

(Trautmann, 2007)

$0.32 \mathrm{~m}^{3} / \mathrm{Kg} \mathrm{COD}$ eli

$0.18(0.12) \mathrm{kWh} /\left(\mathrm{m}^{3}{ }_{\mathrm{Vol}} * \mathrm{~d}\right)$ $0.01 \mathrm{Kg} \mathrm{NaOH} / \mathrm{m}^{3}$ ww

(Urban, 2008)

Own experiments

$$
\begin{gathered}
35(25) \mathrm{m}^{2} \\
1.8 \mathrm{Wh} / \mathrm{m}^{3} \mathrm{ww} \\
1 \\
7 \mathrm{Kg} / \mathrm{m}^{3}
\end{gathered}
$$

(Müller et al., 1999)

(Gujer, 2007)

$54.4 \mathrm{Wh} / \mathrm{m}^{3}$ at $50 \mathrm{~m}^{3} / \mathrm{h}$

$0.53 \mathrm{kWh} / \mathrm{m}^{3}$ at $4 \mathrm{~m}^{3} / \mathrm{h}$

(Gülich, 2010)

(Seepex, 2012)

$$
\begin{gathered}
40 \% \\
43 \% \\
0.75 \mathrm{kWh}_{\text {cold }} / \mathrm{kWh}_{\text {th input }} \\
3 \mathrm{kWh}_{\text {cold }} / \mathrm{kWh}_{\mathrm{el} \text { input }} \\
0.57 \mathrm{Kg} \mathrm{CO}_{2} / \mathrm{kWh}_{\mathrm{el}} \\
0.29 \mathrm{Kg} \mathrm{CO}_{2} / \mathrm{kWh} \\
3.71 \mathrm{Kg} \mathrm{CO}_{2} / \mathrm{kg}
\end{gathered}
$$

(FNR, 2010)

(Quách, 2009)

(Öko Institut e.V., 2010)

(TU Delft, 2010)

* The performance ratio indicates the quotient of cooling energy (output heat) and electrical (compression chiller, CC) or thermal (absorption chiller, $\mathrm{AC}$ ) input energy. In contrast to an efficiency factor, this figure can reach a value $>1$. 


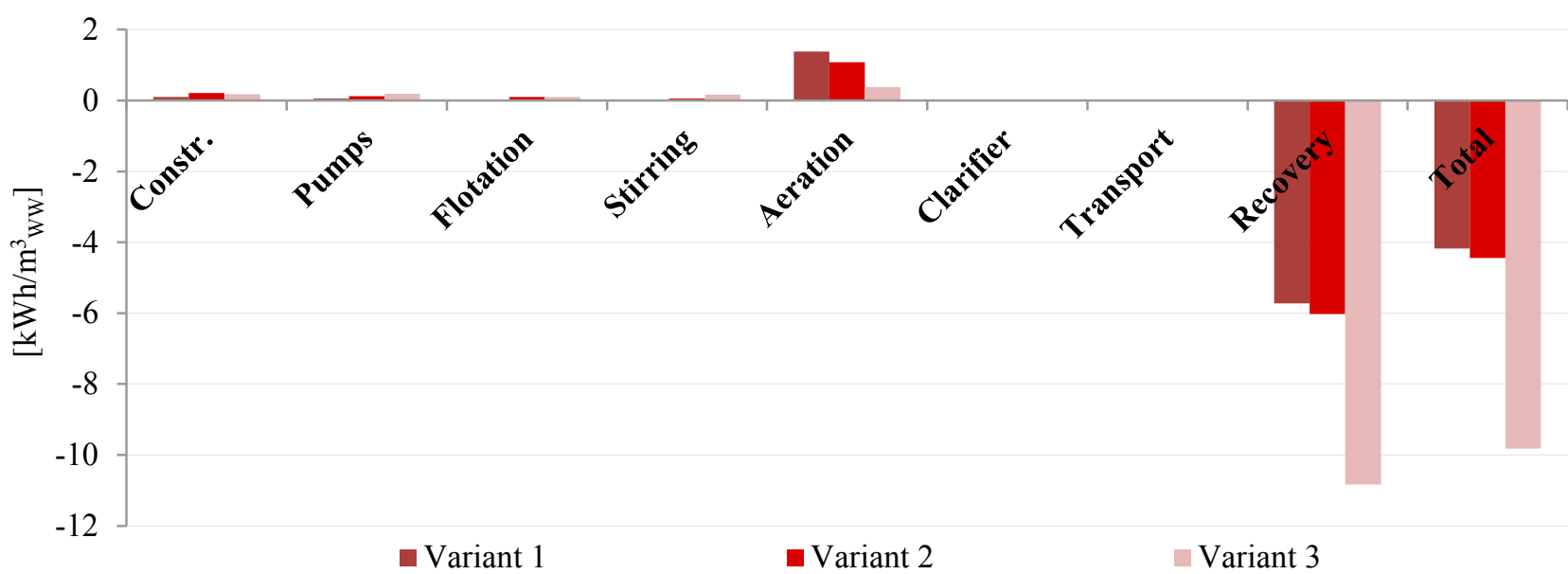

Figure 3. Energy demand and recovery of different process variants

\subsection{Carbon footprint}

The resulting greenhouse gas (GHG) emissions are shown in Figure 4. The emissions strong dependency on the energy consumption causes similar proportions between the different variants. The sum of emissions is also negative in all variants. Construction phase has a lot more impact on the final result, however, since the embodied emissions in the construction materials are considered additionally. Variant 2 has the highest construction complexity and consequently the highest emissions in this category. In total, the emissions in the construction phase add up to $0.12,0.27$ and $0.24 \mathrm{~kg} \mathrm{CO} / \mathrm{m}^{3}$ ww for variants 1 , 2 and 3 respectively.
In the operation phase, variants 2 and 3 save electricity and therefore emissions for aeration compared to variant 1 , but have a higher demand for additional power consumers such as pumps and stirring. Clarifier and transport of chemicals and excess sludge can be neglected in all variants. The emissions of dissolved methane in the outflow of the anaerobic reactors are almost negligible for variant 2 , since the flow rate of the extracted fat is relatively small. In variant 3 , however, dissolved methane is the major source with emissions of $0.34 \mathrm{~kg} \mathrm{CO} / \mathrm{m}^{3}$ ww. The total GHG emissions of the operation phase sum up to a total of $0.82,0.78$ and $0.82 \mathrm{~kg} \mathrm{CO}_{2} / \mathrm{m}^{3}$ ww for the three variants.

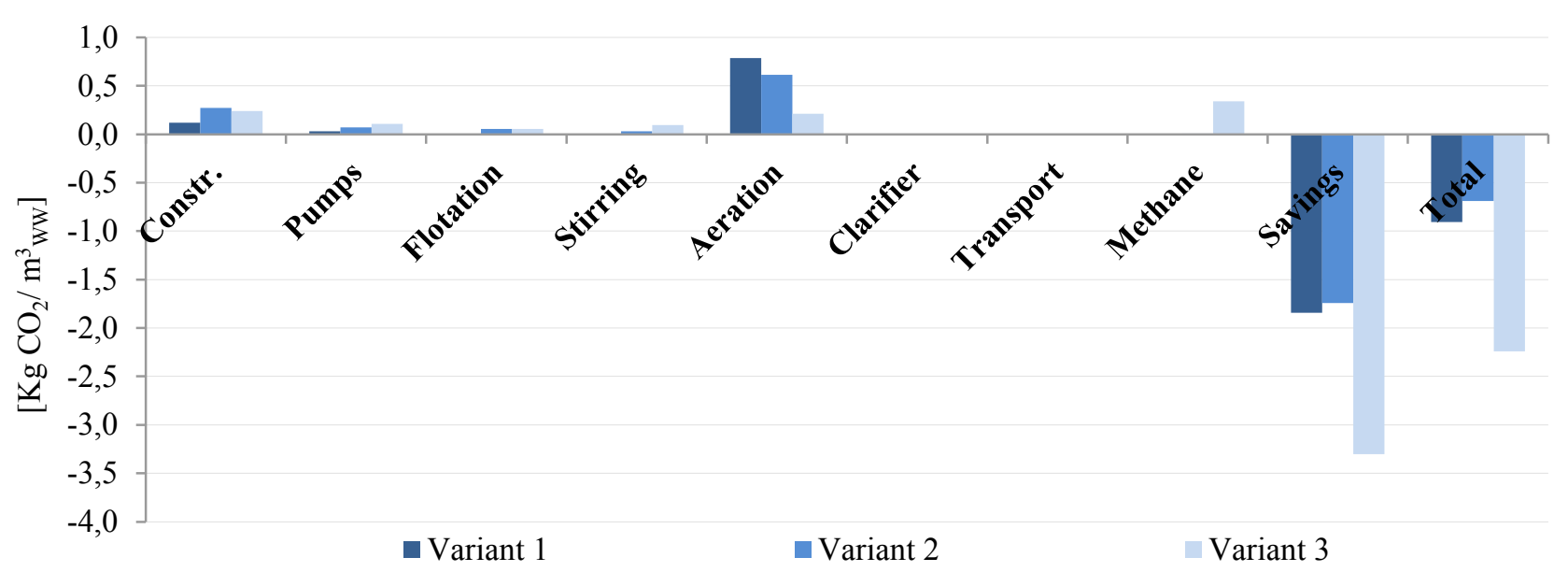

Figure 4. GHG emissions and savings of different process variants

The emission savings depend on both the amount of recovered energy and the method of calculation mentioned in section 2.4. Despite the higher energy recovery, variant 2 performs worse than variant 1 regarding the savings, so the direct substitution of diesel by biodiesel even with a long transport considered turns out to be a more effective way to save emissions compared to the biogas production and conversion in cogeneration units. As compression chillers work quite efficiently, the emission savings by replacing the cooling energy have shown to be low. Because of the higher construction complexity of variant 2 , the difference even grows bigger in the overall performance. Variant 3, however, achieves savings almost twice as high as the other variants. The final carbon footprint of the three variants is $-0.90,-0.69$ and $-2.24 \mathrm{~kg} \mathrm{CO}_{2} / \mathrm{m}^{3}$ ww.

\section{Conclusions}

In this work, energy and carbon footprints over the whole lifespan of three technology variants for wastewater treatment and energy recovery of Vietnamese seafood processing wastewater have been compared. It has been shown that the current technology option has a high net energy output as well as a high negative carbon footprint. The conversion of the fish fat to biogas in variant 2 combined with a modern process technology results in a better energy footprint but due to less effective substitution of fossil fuels and a higher complexity in construction, the carbon footprint is worse. 
Variant 3, in which the fat is converted to biodiesel and the remaining wastewater is pretreated anaerobically, shows a considerable potential for further energy recovery and emissions saving. In total, a net energy output of 9.82 $\mathrm{kWh} / \mathrm{m}^{3}$ ww and a net emissions saving of $2.24 \mathrm{~kg}$ $\mathrm{CO}_{2} / \mathrm{m}^{3}$ ww has been shown to be possible. It has also been proven that the construction phase has a very low impact on both energy and carbon footprints of wastewater treatment plants.

\section{Acknowledgement}

This work was funded by the German Federal Ministry for Education and Research (BMBF) within the scope of the AKIZ Project with the project no. 02WA1066 (www.akiz.de).

\section{References}

[1] Cakir, F.Y., Stenstrom, M.K. 2005. Greenhouse gas production: A comparison between aerobic and anaerobic wastewater treatment technology. Water Research 39(17): 4197-4203

[2] Doorn, M., Towprayoon, S., Vieira, S., Irving, W., Palmer, C., Pipatti, R., Wang, C. 2006. Guidelines for national greenhouse gas inventories. Chapter 6: Wastewater treatment and discharge. Technical report, IPCC

[3] FNR 2010. Leitfaden Biogas: Von der Gewinnung zur Nutzung, Fachagentur Nachwachsende Rohstoffe e.V., Gülzow

[4] Gülich, J.F. 2010. Kreiselpumpen - Handbuch für Entwicklung, Anlagenplanung und Betrieb, 3. Auflage edn, Springer Verlag, Berlin

[5] Gori, R., Jiang, L., Sobhani, R., Rosso, D. 2011. Effects of soluble and particulate substrate on the carbon and energy footprint of wastewater treatment processes. Water Research 45(18): 5858-5872

[6] Gujer, W. 2007. Siedlungswasserwirtschaft, 3 Edn, Springer Verlag, Heidelberg

[7] Henze, M., Gujer, W., Mino, T., van Loosedrecht, M. 2000. Activated Sludge Models ASM1, ASM2, ASM2d and ASM3. IWA Publishing

[8] Jayasinghe, P., Hawboldt, K. 2012. A review of biooils from waste biomass: Focus on fish processing waste. Renewable and Sustainable Energy Reviews 16(1): 798-821

[9] Jensen, K., Thyø, K., Wenzel, H. 2007. Life Cycle Assessment of Biodiesel from Animal Fat, Daka, Dänemark (retrieved on 07.11.2012) http://www.dakabiodiesel.com/lib/files.asp?ID=518

[10] Öko Institut e.V. 2010. Gemis Datenbank, Öko Institut e.V., Freiburg (retrieved on 17.12.2012). www.gemis.de

[11] Larsen, H., Hauschild, M., Wenzel, H., Almemark, M. 2007. Homogeneous LCA methodology agreed by NEPTUNE and INNOWATECH, NEPTUNE and INNOWATECH, Switzerland
[12] López, D.E., Mullins, J.C., Bruce, D.A. 2010. Energy life cycle assessment for the production of biodiesel from rendered lipids in the United States. Industrial and Engineering Chemistry Research 49(5): 2419-2432

[13] Meador, M., Scott, R., Junyang, J. 2012. China Peoples Republic of. Biofuels Annual. Technical report, U.S. Department of Agriculture - Foreign Agricultural Service (GAIN Report Number: 12044)

[14] Müller, E., Kobel, B., Künti, T., Pinnekamp, J., Seibert-Erling, G., Schaab, R., Böcker, K. 1999. Handbuch Energie in Kläranlagen. Ministerium für Umwelt, Raumordnung und Landwirtschaft des Landes Nordrhein-Westfalen

[15] PAS2050 2011. Publicly available specification: Specification for the assessment of the life cycle greenhouse gas emissions of goods and services, British Standards Institution, UK

[16] Quách, T. 2009. Study, Definition of Vietnam Grid Emission Factor. Ozone Layer Protection Centre and Department of Meteorology, Hydrology and Climate Change, Vietnam

[17] Rosso, D., Larson, L.E., Stenstrom, M.K. 2008. Aeration of large-scale municipal wastewater treatment plants: state of the art. Water Science and Technology 57(7): 973-978

[18] Seepex 2012. Seepex Exzenter-schneckenpumpen: Leistungsdaten, Seepex Gmbh, Bottrop

[19] Shahabadi, B., Yerushalmi, L., Haghighat, F. 2009. Impact of process design on greenhouse gas (ghg) generation by wastewater treatment plants. Water Research 43(10): 2679-2687

[20] Steinke, M., Barjenbruch, M. 2010. Full-scale experiences of nitrogen removal of fish-processing wastewater with flotation and anoxic-aerobic activated sludge system. Water Science and Technology 61(9): 2227-2233

[21] Trautmann, N. 2007. Abbildung einer halbtechnischen Versuchsanlage (UASB) zur anaeroben Kommunalabwasserbehandlung mit dem Anaerobic Digestion Model No. 1. Master's thesis, Leibniz Universität Hannover

[22] Trautmann, N., Beier, M., Phan, L., Rosenwinkel, K. 2011. A new approach to energy-efficient treatment of wastewater produced by the fish industry in Vietnam. Water Science and Technology 64(1): 279-285

[23] TU Delft 2010. Idemat Datenbank, TU Delft (retrieved on 17.12.2012). www.idemat.nl

[24] Urban, I. 2008. Anaerobe Kommunalabwasserbehandlung - Einsatz und Bemessung von UASB - Reaktoren, $\mathrm{PhD}$ thesis, Leibniz Universität Hannover

[25] VEA 2008. QCVN 11:2008/BTNMT. National Technical Regulation on the effluent of the aquatic products processing industry. Vietnam Environment Administration and Department of Legislation and Ministry of National Resource and Environment 
[26] Zhang, Z., Wilson, F. 2000. Life-cycle assessment of a sewage-treatment plant in South-East Asia. Journal of the Chartered Institution of Water and Environmental Management 14(1): 51-56
[27] Ziegler, F. 1998. Sorptionswärmepumpen: Beschreibung des Betriebsverhaltens durch eine charakteristische Gleichung. Technische Sorptionsprozesse, Fortschrittsbericht des VDI 544, 259 - 279 